\title{
Morphological and functional peculiarities of saltmarsh plants and epilithic lichens in tidal conditions of Russian Arctic Seas
}

\author{
Evgeniya Markovskaya, Angella Sonina, Liudmila Sergienko*, Kira \\ Morosova, Nadezhda Elkina
}

Petrozavodsk State University, Ecological-biological Faculty, Department of Botany and Plant Physiology, Lenina, 33, Petrozavodsk 185910, Russia

\begin{abstract}
Ecological plasticity in the tidal zone, specifically the effects of daily and seasonal dynamics of environmental factors on the dominant species of vascular plants and epilithic lichens has been studied. The investigations were conducted on the Pomorian coast of the White Sea (Republic of Karelia) during two growing seasons (2012-2013). The studies of the morphological and anatomical characteristics of dominant individuals in the plant and lichen cover types have been made along the model transect through different substrate types. Determination of plasticity of plants and lichens was made by the method of Cornelissen exploiting coefficient of variation (CV). The obtained data showed that the investigated groups of vascular plants and lichens on the tidal zone on all measured morphological and anatomical parameters have a high level of plasticity
\end{abstract}

Key words: tidal zone, coefficient of variation, vascular plants, lichens, pollen, anatomy, White Sea.

DOI: $10.5817 / \mathrm{CPR} 2014-2-17$

\section{Introduction}

Water is rather stable environment, and it's abiotic factors have relatively only minor fluctuations. Thus, aquatic organisms have smaller ecological plasticity in comparison with the terrestrial ones. However, in the tidal zone, where all the factors constantly vary in daily and seasonal dynamics, plants and animals inhabiting such habitats must cope with high instability of environmental conditions (Sergienko et al. 2012). This leads to an increased plastici- ty of the species (the increase in the amplitude of the phenotypic variation) and, as a result, to strengthening their morphogenesis and speciation. Ecological plasticity underlies in the intraspecific polymorphism that has been investigated recently (Engels at al. 2011, Sheremetiev 2005, Sergienko 2008). However, the plant populations growing in the tidal zone of the Holarctic seas, their plasticity in particular, have not been studied. The purpose of this study is

Received November 21, 2014, accepted December 30, 2014.

*Corresponding author: Liudmila Sergienko <muddycoast@gmail.com>

Acknowledgements: The study was made within the frame of project No. 6.724.2014 (The fulfilment of State tasks of the Ministry of Education and Science of Russian Federation). 
the investigation and evaluation of the variation of some morphological and functional characteristics of phototrophic organisms: vascular plants and lichens of the

\section{Material and Methods}

The study was conducted along the Pomorian coast of the White Sea, near the village Rast-Navolok (White Sea region, Republic of Karelia) during two consecutive growing seasons (2012-2013). The investigated area of the White Sea coast is located in sub-physiographic zone in the North of European part of Russia. White Sea, connecting with the Barents Sea, is the part of the Arctic ocean (Markovskaya et al. 2010) (see Fig. 1). The study area coastal zone of the White Sea, evaluation of their adaptation to unstable environmental conditions in particular.

was located in the tidal zone of the coastline of the White Sea - from the zero level (the littoral zone) to supralittoral (splash zone). The phototrophic organisms thriving in such high/latitude ecotypes of the coastal zone (vascular plants, lichens) cope with low temperature, seasonal variations of photoperiod, daily gradient of temperature and light conditions, flood, and salinity.

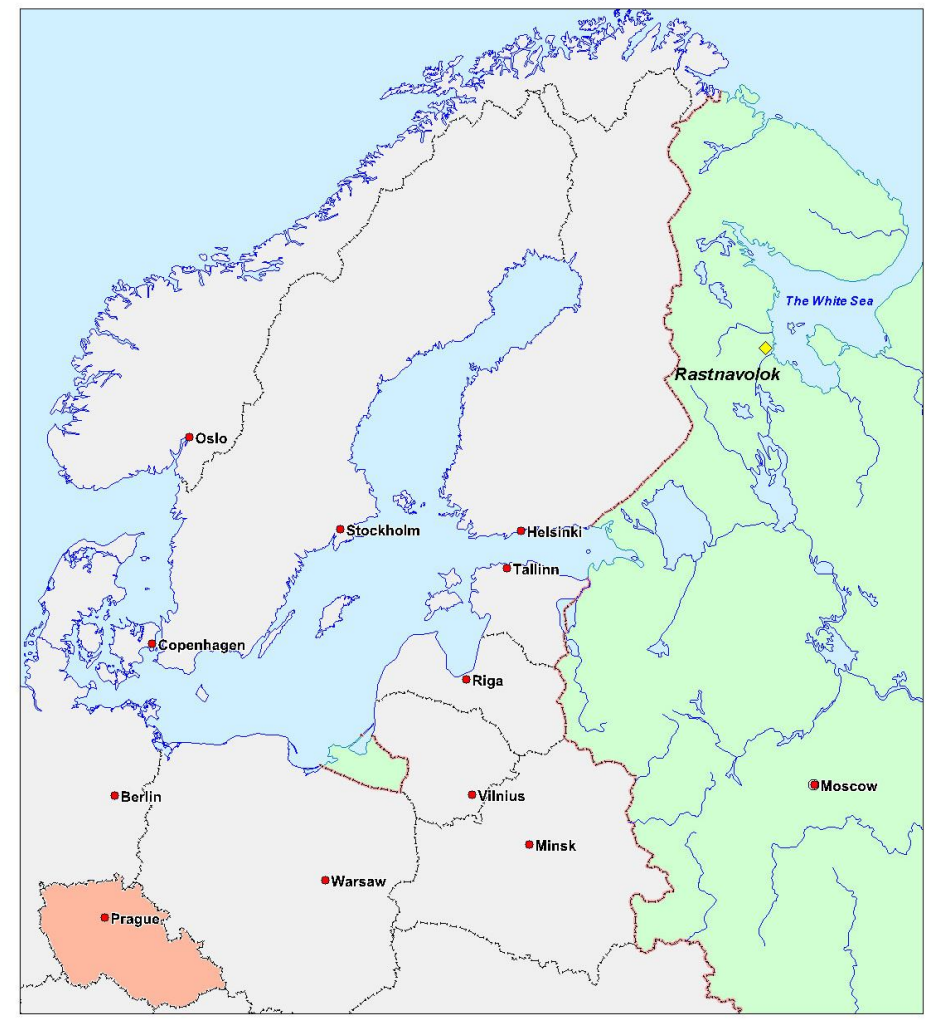

Fig. 1. Study area - Rastnavolok - Belomorsk district, Karelia Republic. 
The distribution of vascular plants and epilithic lichens on the coast was assessed. Similarly, the study of morphological characteristics of dominant individuals in the plant and lichen cover types were evaluated along the model transects (length $260 \mathrm{~m}$, width $10 \mathrm{~m}$ ). The transect begun from the native coast, formed of stone boulders, height up to $2.5 \mathrm{~m}$ and followed up to the line of low-water's edge at low tide. Different length of time tiding in the full tide the three plots (PPs - see below), were found along the transect, the shapes of which coincide with the natural boundaries of plant communities.

PP $1(3 \times 6 \mathrm{~m})$ was located in the distance of $5 \mathrm{~m}$ from the maximum low tide from the water's edge. The plot was typical by muddy and sand substrate. The height of the column of water from the substrate to the maximum high tide reached 100-120 $\mathrm{cm}$. TPC of vegetation was below $10 \%$.

PP $2(4 \times 5 \mathrm{~m})$ was located in the distance of $80 \mathrm{~m}$ from the water's edge. The plot was typical by muddy and sand substrate. The height of the column of water from the substrate was up to $80 \mathrm{~cm}$. (TPC) vegetation ranged $30-40 \%$.

PP $3(4 \times 5 \mathrm{~m})$ was located in the distance of $140 \mathrm{~m}$ from the water's edge. The plot was typical by muddy and sand substrate. The height of the column of water from the substrate was up to $60 \mathrm{~cm}$. (TPC) vegetation ranged $70-80 \%$.

PP $4(4 \times 5 \mathrm{~m})$ was located in the distance of $230 \mathrm{~m}$ from the water's edge. The height of the water column above the substrate during the complete flow was up to $40 \mathrm{~cm}$. Total projective cover (TPC) of vegetation reached $50-60 \%$.

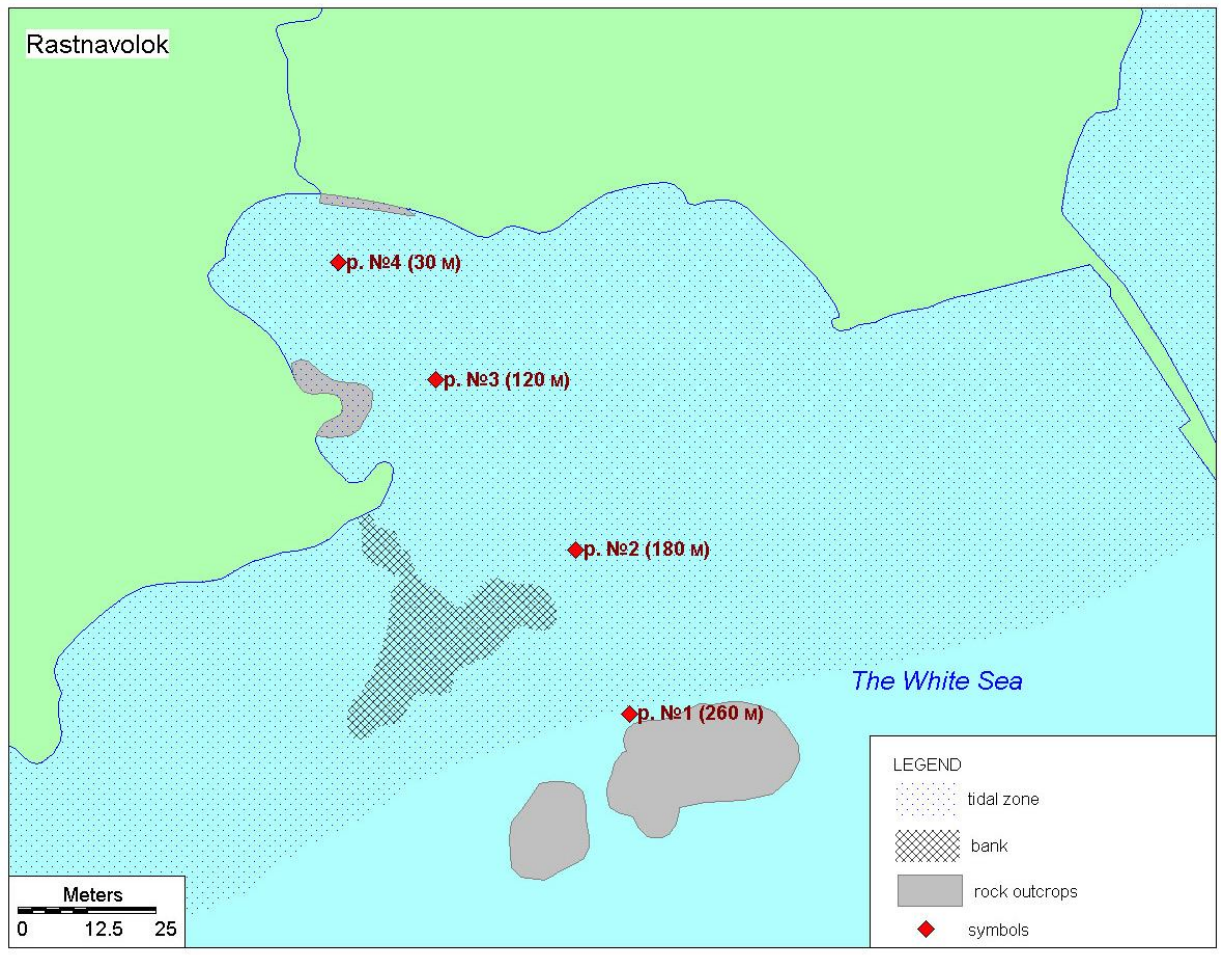

Fig. 2. Plots on the transect on the tidal zone on the shore of White Sea. 
For plants, several morpho-physiological parameters were investigated: (1) plant height, (2) width and length of the lamina, (3) lamina area (S), (4) dry weight of leaf (m), (5) specific leaf area (SLA). Anatomicmorphological characteristics represented the following parameters: (6) the cell volume, (7) number of stomata, (8) size of stomata, (9) area of the stomatic cleft on the upper and lower sides of the lamina, (10) length and width of the cells of the upper and lower epidermis, (11) length and width of the cells of the palisade mesophyll, (12) number of chloroplasts in the spongy and the palisade mesophyll, (13) total number of chloroplasts, (14) cell volume corresponding to one chloroplast (KOH) the amount of cells corresponding to one chloroplast or cell volume of the chloroplast (i.e. the ratio of the volume of cells to the number of chloroplasts in its $\left(\mathrm{mcm}^{3}\right)$.

In this study, palynological parameter, i.e. determination of percentage of pollen violation in dominant vegetation species was estimated. 10 viable, well-developed and well-lighted plants in each plot were selected. 5 leaves from the middle part of the stem for fixation in $70 \%$ ethanol were taken from each plant. For palynological studies for each species 10 flowers from 1 plant was taken.

50 leaves were determined by their size and measurement of anatomical structures (stomata cells of the epidermis and mesophyll) - 10 lamina from different individuals of each species from each PP. The plant material was dried in a thermostat at $60^{\circ} \mathrm{C}$ until constant weight, for determine of dry mass. Measurements of anatomical parameters were carried out using a light microscope with magnification of $100 \mathrm{x}$ 100-fold replication for leaves from each plot. The number of chloroplasts was calculated as an indicator of stomatal apparatus according to the method of Mokrousov et Borzenkova (1978). For analysis of pollen grains, the acetocarmine method (Pausheva 1980 , Dzyuba 2006) was used. Determination of plasticity $(\mathrm{CV})$ of plants and lichens was done by the method of Cornelissen et al. (2003). The morphophysiological, anatomical and palynological studies on the dominant higher vascular species of the salt marshes communities (Glaux maritima, Tripolium pannonicum subsp. tripolium, Triglochin maritima, Plantago maritima), were done at the selected transects. In Glaux maritima and Tripolium pannonicum subsp. tripolium the anatomical and morphological studies were performed. The variations of the halophytic species (Sonina 2012) (species of the genus Verrucaria) was used as characteristics of the lichen cover.

\section{Results}

Glaux maritima L. - crynohalophyte, is common on the White Sea coast in salt marshes communities on the West coast. It is rare at other parts of the coast. The species has a disjunctive geographical range in the temperate zone of the Northern hemisphere. The results can be summarized as follows: (1) the number and the size of stomata on the upper side and the lower sides of the lamina, and (2) the cell volume increased with the distance from the shore to the water's edge on three plots.

The only two above-specified characteristics significantly differed in Glaux maritima. Other morphological, physiological and anatomical parameters considered in the analyzed plants did not showed significant changes along the transect.

However, the heterogeneous conditions along a transect caused some changes in the coefficient of variation. Morphophysiological parameters changed along the transect and had values of coefficient of variation $(\mathrm{CV})$ in the range: leaf surface 
area values $537-424 \mathrm{~mm}^{2}$ (CV 15-37\%), length $(1.0$ to $1.1 \mathrm{~cm})$ and the width of the sheet $(0.43-0.52 \mathrm{~cm}) \mathrm{CV}(5-30 \%)$, SLA $\left(11.0-14.0 \mathrm{~mm}^{2} \cdot \mathrm{mg}^{-1}, \mathrm{CV}\right.$ range of $8-$ $31 \%)$, dry matter content $\left(214-245 \mathrm{mg}^{-1} \mathrm{~g}^{-1}\right.$, CV 12-26\%).

In the morpho-anatomical parameters, the following range of values was found: volume of cells (to 12.0-17.0 thousand

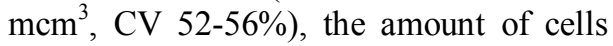
corresponding to one chloroplast $\mathrm{KOH}$ (460-490 $\mathrm{mcm}^{3}$, CV 54-59\%), the number of chloroplasts, especially in the cells of the spongy parenchyma (28-36 units in the cell, CV 25-36\%). The variation of the above-specified characteristics generally did not exceed $20-22 \%$. The most variable parameters were found in the plants growing in the middle plots along the the transect, where the coverage of vegetation reached $70 \%$, the abundance of Glaux maritima growing in the shaded spots provided by a taller species, was up to $30 \%$.

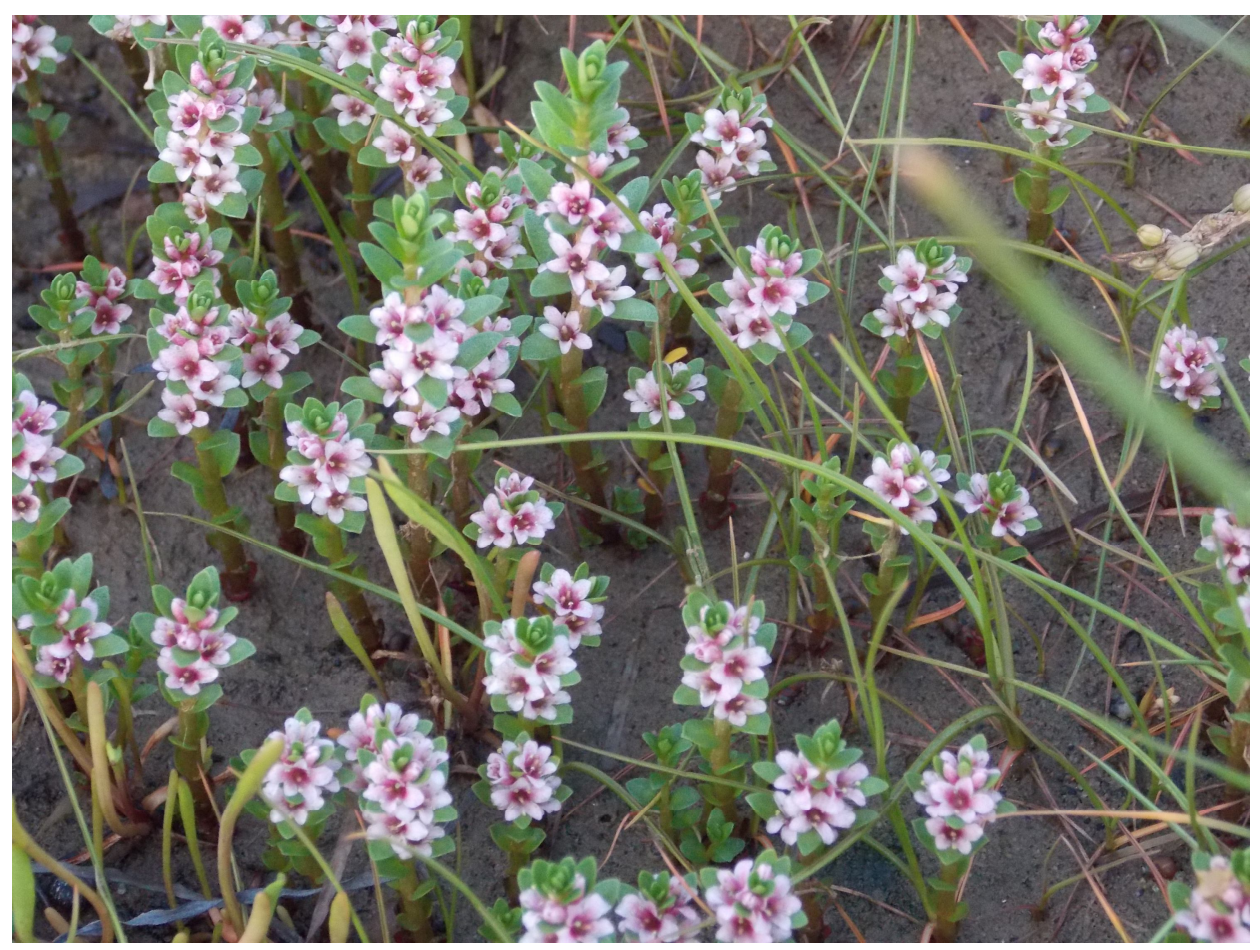

Fig. 3. Glaux maritima on sand substrate on transect on the tidal zone on the shore of White Sea.

Tripolium pannonicum (Jacg.) Dobrocz. subsp. tripolium (L.) Greuter - euhalophyte, boreal Eurasian species, is commonly spread on the coast of the Holarctic (Markovskaya et al. 2010). The plant height and the area of the lamina were found significantly reduced as the species moves from the native coast to the water's edge. The thickness of the lamina reached almost $20 \%$ at the water's edge. In the plants growing near water's edge, the morpho-physiological and morpho-anatomical parameters of plant (number of stomata on both upper and lower epidermis) increased as well.

However, the heterogeneous conditions along the transect caused changes of the coefficient of variation of particular charac- 
teristics. The highest $\mathrm{CV}$ values were found for the leaves area: the area values was about 460-1980 $\mathrm{mm}^{2}$ (CV 39-56\%). The CV showed somewhat lower values for the length $(7-15 \mathrm{~cm})$ and the width of the sheet $(0.6$ to $1.3 \mathrm{~cm})$ : $\mathrm{CV}$ was $26-35$ and CV 26-33\%, respectively. Mean values and $\mathrm{CV}$ reached $8-14 \mathrm{~mm}^{2} \cdot \mathrm{mg}^{-1}$, and $29-30 \%$ for SLA and $150-160 \mathrm{mg} \cdot \mathrm{g}^{-1}$, and $26-41 \%$ for dry mass respectively.

The highest values of $\mathrm{CV}$ were obtained on the volume of cells (20-23 thousand $\mathrm{mcm}^{3}, \mathrm{CV} 42-46 \%$ ) and $\mathrm{KOH}$ (380-470 $\left.\mathrm{mcm}^{3}, \mathrm{CV} 38-59 \%\right)$. All characteristics of the stomatal apparatus of
Tripolium pannonicum had lower CV values than in Glaux maritima. It was found for number of stomata per unit area: the values ranged 45-90 pieces $/ \mathrm{mm}^{2}$ (CV 25$36 \%$ ), the area of the stomatic cleft were found within a range of $33-38 \mathrm{mcm}^{2}(\mathrm{CV}$ $25-35 \%$ ), the area of stomata on the upper and lower side of the lamina was 700-890 $\mathrm{mcm}^{2}$ (CV 22-40\%), 910-1130 $\mathrm{mcm}^{2}$ (CV $12-37 \%)$, respectively. The range of $\mathrm{CV}$ for the other parameters was not found too high, CV was found within a range from 10 to $20 \%$. When comparing data from all three plots, large differences in the coefficient of variation was not found.

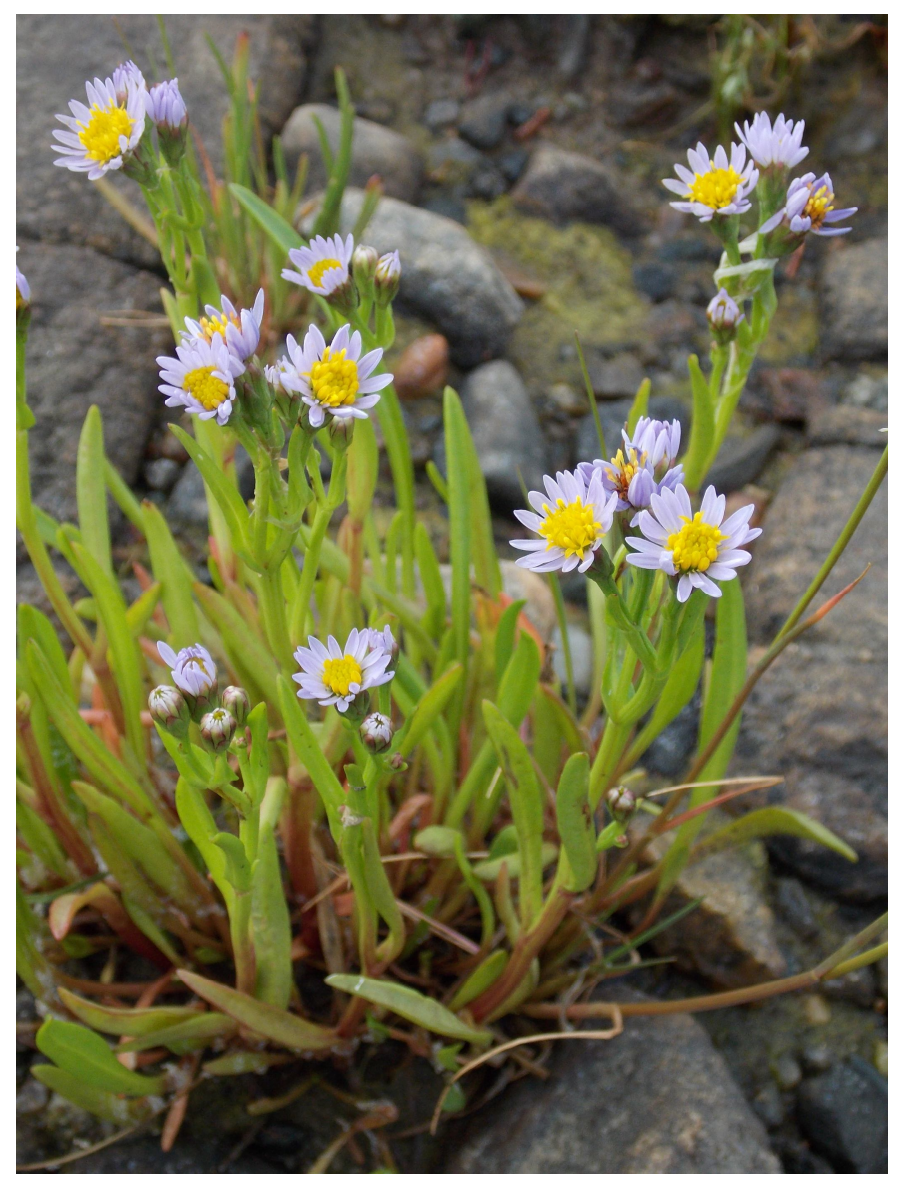

Fig. 4. Tripolium pannonicum subsp. tripolium on pebble-shingle substrate on transect on the tidal zone on the shore of White Sea. 
Triglochin maritima L. - euhalophyte, plurizonal species, has a circumpolar area, occurs all over on the White Sea coast in the salt marshes communities with high content of salt (Markovskaya et al. 2010). The plants of Triglochin maritima growing at water's edge (PP3) the leaf area compared to other points on the transect have been decreased, while the other parameters were not significantly changed during the flooding duration. The coefficient of variation of leaves area: the area values is about $990-1380 \mathrm{~mm}^{2}$ (CV 22-50\%), the length of leaves $-28-37 \mathrm{~cm}$ and the width of the lamina - 0.3-0.4 cm (CV 5-30\%); on the SLA - 3.3-3.8 $\mathrm{mm}^{2} \cdot \mathrm{mg}^{-1}$ (CV 17$35 \%)$ and the dry matter content $240-260$ mg.g ${ }^{-1}$ (CV 18-39\%).

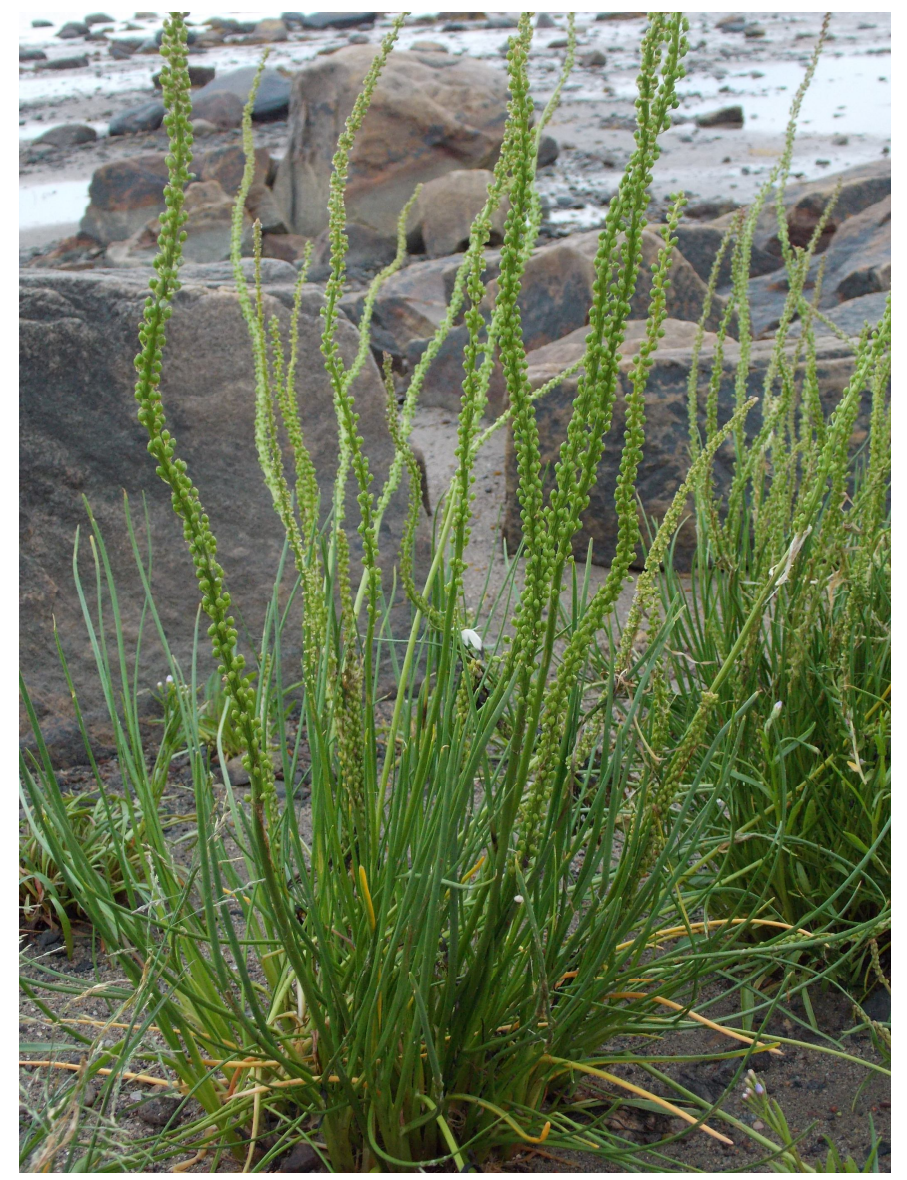

Fig. 5. Triglochin maritima on sandy-boulder substrate on transect on the tidal zone on the shore of White Sea.

Plantago maritima L. is a euhalopyte, hypoarctic Eurasian species, abundant on the coast of the White Sea. The species widely occurs in the area of periodic inundation by salt water (Markovskaya et al.
2010). The increasing of the number of indicators for Plantago maritima in different tidal conditions was noted. The increasing in the values of the number of indicators for Plantago maritima in differ- 
ent tidal conditions was noted. The specific leaves area (SLA) and the accumulation of dry mass significantly increased in the plots at the water's edge. The plants of Plantago maritima had the following values of the means and CVs: for the leaves area $\left(650-1500 \mathrm{~mm}^{2}, \mathrm{CV} 54-81\right)$, the length (14-24 cm) and the width of the lamina $(0.4$ to $0.6 \mathrm{~cm})(\mathrm{CV}$, accordingly $34-100 \%$ and $25-45 \%)$, SLA $\left(9-12 \mathrm{~mm}^{2}\right.$. $\mathrm{mg}^{-1}, \mathrm{CV} 34-97 \%$ ), and dry matter content (170-210 mg.g $\mathrm{g}^{-1}$, CV 22-31\%).

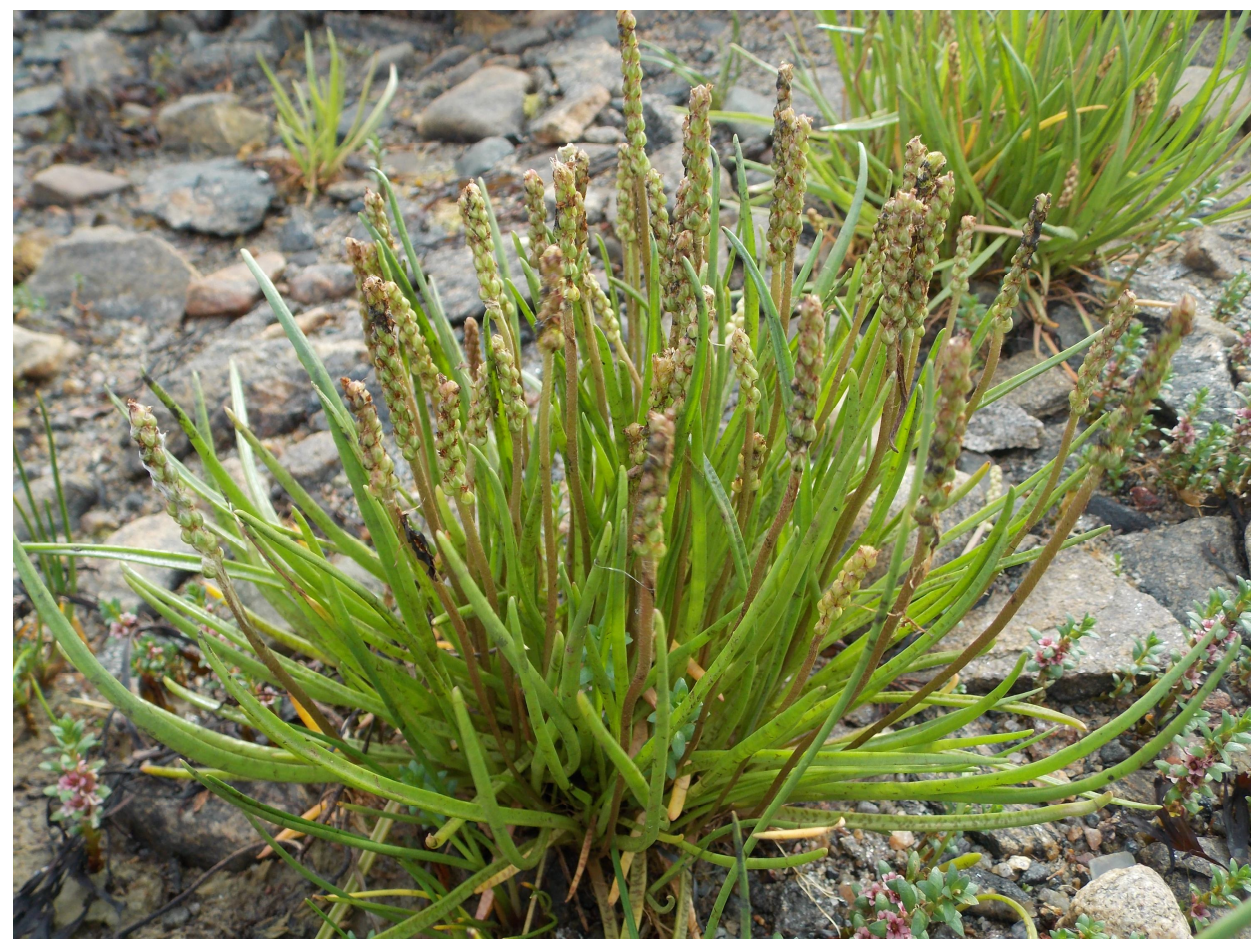

Fig. 6. Plantago maritima on sandy-break stone substrate on transect on the tidal zone on the shore of White Sea.

The stage of formation of reproductive structures is one of the indicators of the functional state of the plant. Therefore, the structure of pollen grains in the three species -Triglochin maritima L., Tripolium pannonicum (Jacg.) Dobrocz. subsp. tripolium (L.) Greuter, Glaux maritima L. was investigated. The three species grow in the tidal zone which is typical by a high frequency of changes in abiotic factors of the environment. The changes happen from the native shore to the water's edge. That was why the structure of pollen grains was investigated. The value of the coefficient of variation of normally developed pollen within transect at Tripolium pannonicum subsp. tripolium was found from 3.0 up to $5.0 \%$ The value indicated a weak variation of this parameter and may be attributed to a long-term adaptation of this species to a wide range of conditions generated at the tidal zone.

The value of the $\mathrm{CV}$ of normally developed pollen within transect at Glaux maritima was 2.0 - $16.0 \%$, indicating a moderate degree of variation. The $\mathrm{CV}$ value of normally developed pollen within transect at Triglochin maritima was found 
from 6.0 to $48.0 \%$. The highest $\mathrm{CV}$ values was recorded for Triglochin maritima grown in the central part of the transect (PP2) (CV 48.0\%). This particular site was an open area with the most active tidal dynamics to which this species may respond.

The halophytic group of lichens of the genus Verrucaria, forming spots of different sizes depending on habitat conditions were found only in flooding areas on the stones. On all investigated plots along

\section{Discussion}

In this study, we compared $\mathrm{CV}$ values calculated for several morpho-physiological parameters in the investigated higher plant species. We considered the CV values as a measure of flexibility of the species at the site. The main conclusions can be summarized as follows: (1) high level of plasticity was found for Plantago maritima, while the lower $\mathrm{CV}$ values were in Triglochin maritima and Tripolium pannonicum subsp. tripolium, (2) the lowest level of plasticity had Glaux maritima (Crawford, 2011), (3) high CV values of morpho-physiological parameters were observed in all individuals of all species growing near water's edge. In morpho-anatomical parameters, the following two species (Tripolium pannonicum subsp. tripolium and Glaux maritima) were compared. It was found, that (4) Tripolium pannonicum subsp. tripolium had a larger number of indicators with a high level of variation compared with Glaux maritima. Therefore, we suppose that Tripolium pannonicum subsp. tripolium is more plastic than the plants of Glaux maritima in response to environmental perturbations.

Preliminary analysis of the development of reproductive structures showed that the investigated species of higher plants can be ranked according to high to low plasticity as follows: Triglochin maritima, Glaux maritima and Tripolium transect, the projective lichen cover degree has the high values of $\mathrm{CV}$, i.e. from 34 to $88 \%$. At the sites along the transect where the highest $\mathrm{CV}$ values were found, the total average cover of lichen halophytes reached $30 \%$. Contrastingly, at the water's edge, the $\mathrm{CV}$ value was found low $(\mathrm{CV}=$ $34 \%$ ). At the plots located closer to a native shore, the CV values increased to 83$88 \%$, while the projective cover showed somewhat lower values (below 5\%).

pannonicum subsp. tripolium. For lichen of genus Verrucaria, a conclusion can be made that the pattern of its the distribution on the intertidal zone is associated with rising of salt water along the transect. Salt water is a essential condition for the existence of such halophytic genus like Verrucaria. At the water's edge at low tide on the rocks lichens have the greater projective cover in those micronches that are longer under the column of salt water. Near the native shore lichens can be found only in those micronches on the rocks, which at least are in the zone of influence of marine waters.

The highest CV values for projective cover of halophytic species of lichens were found near the native shore (CV 88\%) in long-term low tide. The lowest $\mathrm{CV}$ value was found for the sites typical by longterm flooding and high water lifting. These sites were located near the water's edge (CV 34\%). The differences in flood and water lifting dynamics led to the selection of the most stable to unsteady conditions of individuals of species of the genus Verrucaria.

The data presented in this study showed that the investigated groups of vascular plants and lichens morphological and anatomical parameters have a high level of plasticity (evaluated as $\mathrm{CV}$ variation) for the species forming vegetation cover of tidal zone. Only one species - Glaux 
maritima had $\mathrm{CV}$ values as low that a conclusion of low morphological plasticity of the species can be done. The data presented in this study support the idea of a more detailed investigation in this field, at least as a continuation of recent study.
For future studies, enlargement of the scope is recommended as regards e.g. an inclusion of some new species and the extension of the indicators of vegetation structure and function.

\section{References}

Cornelissen, J. H. C., Lavorel, S., Garnier, E., Díaz, S., Buchmann, N., Gurvich, D.E., Reich, P.B., ter Steege, H., Morgan, H.D., van der Heidden, M.G.A., Pausas, J.G. and Poorter, H. (2003): A handbook of protocols for standardised and easy measurement of plant functional traits worldwide. Australian Journal of Botany, $51: 335-380$.

CRAWFORD, R. (2011): Ecological Integrity Assessment: Temperate Pacific Tidal Salt and Brackish Marsh: 1-11.

DzYuBA, O. F. (2006) : Palynoindication of environmental quality. Nedra, SPb, 2006. 198 p.

ENGeLs, J. G., RinK, F. and Jensen, K. (2011): Stress tolerance and biotic interactions determine plant zonation patterns in estuarine marshes during seedling emergence and early establishment. Journal of Ecology, 99 : 277-287.

Markovskaya, E. F., Sergienko, L. A., Sonina, A. V., Starodubtseva, A. A. and Smolkova, O. C. (2010): Natural complex of the coasts of the White sea. Karelian Research Centre, Russian Academy of Sciences, Petrozavodsk, 2010. 85 p.

Mokrousov, A. T., Borzenkova, R. A. (1978): The measurement of patterns of functional activity of photosynthetic tissues and organs. In: Procceeding on applied botany, genetics and plant breeding. Nauka, Moscow, is.61, vol. 3, pp. 119-133.

PausheVA H. P. (1980): Practical course on the cytology of plants. Agropromizdat, $304 \mathrm{p}$.

Sergienko, L. A. (2008): Flora and vegetation of the coasts of the Arctic and adjacent areas Petrozavodsk University Publishing Association, Petrozavodsk, $225 \mathrm{p}$.

SergienKo, L., Markovskay a, E. and StarodubcheVA, A. (2012): Distribution of vascular plants in the coastal ecosystems of the White Sea. In: P. Gâştescu, W. Lewis Jr., P. Breţcan (eds.): Water resources and wetlands. Conference Proceedings, 14-16 September 2012, Tulcea Romania, pp. 396-401.

SHEREMETIEV, S. N. (2005): Grass on the gradient of soil moisture (water exchange and structuralfunctional organization). The partnership of scientific publications, KMK, $271 \mathrm{p}$.

SonINA, A. V. (2012): Epilithic lichens and their morphological adaptations to the conditions of the White and Barents Seas coast (Russian Arctic). Czech Polar Reports, 2: 109-116. 